\title{
POWER POINT OR CHALK AND BOARD - STUDENTS VIEW TOWARDS METHOD OF TEACHING ANATOMY
}

\author{
Rashmi C Goshi.
}

Assistant Professor, JSS M edical College, M ysuru, Karnataka, India.

\section{ABSTRACT}

Background: Traditionally most of the lectures are taken with chalk and board in India. However with economic growth, the use of computer assisted techniques is inevitable. The use of power point presentations has been increasingly adopted by many of the medical colleges.

Aim: Present study assesses the student's perspectives and preferences for chalk and board and power point.

Materials and M ethods: Twelve lectures were delivered to $1^{\text {st }} \mathrm{MBBS}$ students, each of 45 min -6 by $C \& B$ and 6 by PPT. students were given a questionnaire seeking their opinions about helpfulness of teaching tools for reproducibility of diagrams and text in examination, retention of lecture information in memory and understanding of simple and complex concepts.

Conclusion: We feel that PPT should be used as supplementary to enhance the efficacy of teaching. As suggested by recognizable number of students, both methods should be used in combination, as per need of the topic.

KEY WORDS: Lecture, Teaching, chalk and board, PPT, Efficacy.

Address for Correspondence: Dr Rashmi C Goshi, Assistant Professor, Department of Anatomy, JSS M edical College, Shivrathreeshwara Nagara, Mysuru - 15, Karnataka, India.

E-Mail: rashmigoshi@gmail.com

\begin{tabular}{|c|c|c|}
\hline \multicolumn{3}{|c|}{ Access this Article online } \\
\hline \multirow{3}{*}{ Quick Response code } & \multicolumn{2}{|c|}{$\begin{array}{l}\text { Web site: International Journal of Anatomy and Research } \\
\qquad \text { ISSN 2321-4287 } \\
\text { www.ijmhr.org/ijar.htm }\end{array}$} \\
\hline & $\begin{array}{l}\text { Received: } 23 \text { Dec } 2016 \\
\text { Peer Review: } 23 \text { Dec } 2016\end{array}$ & $\begin{array}{l}\text { Accepted: } 06 \text { Feb } 2017 \\
\text { Published (0): } 28 \text { Feb } 2017\end{array}$ \\
\hline & Revised: None & Published (P): 28 Feb 2017 \\
\hline
\end{tabular}

\section{INTRODUCTION}

Lecture is the commonest form of teaching since ancient times [1]. It has been a universally accepted way of teaching, and adapted in almost all universities, including medical ones. Although discussion in small groups appears to be a superior method of attaining higher level intellectual learning [2], it is almost inevitable that the medical students attending is too large in comparison to the teaching staff available.

Hence as Walton, 1972 notes; The lecture is here to stay, so it is imperative that it should be as effective as possible [3].

Teaching aids like chalk and board, power point
(PPT), have been used in anatomy teaching. Chalkboard aid is inexpensive, easy to clean and reuse, allows students to keep pace with the teacher and is not dependent on electricity. However it is time consuming, one cannot go back to what has been erased and is not so effective for large no of students [4].

With an increasing number of medical seats and an extensive syllabus, there has been a constant effort to use modern teaching aids in medical colleges. Audiovisual aids like PPT help to illustrate pathway and mechanism diagrams and impart clarity to the lectures. PPT has the advantages of using colors, fonts, diagrams and animation [4]. 
Ability to explain, make students understand a concept is an important skill of a good teacher. In addition, while learning Anatomy, some facts need to be remembered as they are, as no logic is applicable to them. Assessment of student performance in anatomy cannot be complete without assessing the ability to draw accurate, proportionate and well labeled diagrams. Thus we feel that teaching method for anatomy should be assessed under three domainsunderstanding the concept, retention of lecture information in memory and reproducibility of diagrams. So also the student perspective and preference to a particular method should be considered.

Aims and Objective: To assess students perspectives for chalk- board and PPT for gross anatomy lectures, to assess students preference for chalk-board and PPT for gross anatomy lectures.

\section{MATERIALS AND METHODS}

The study was conducted in Department of Anatomy, JSS M edical College. The $1^{\text {st }}$ MBBS students were briefed about the study and were appealed to participate. All 160 students participated in study, voluntarily.

Twelve lectures of Anatomy were selected randomly, six of which were taken using chalk and board and six by using PPT. List of questionnaire was prepared, opinions of students were sought about helpfulness of the tools as far as reproducibility of text and diagrams in examination, understanding and memorization of lecture information is concerned.

\section{RESULTS}

From the table it is seen that students feel $C \& B$ is better than PPT as far as conceptual understanding, memorization of topic, reproducibility of text information and diagrams is concerned, the difference is statistically significant. $55 \%$ of our students felt that $C \& B$ is interesting method of teaching compared to $45 \%$ favoring PPT. When asked which method should be used $56 \%$ students polled in favor of $C \& B$.

Reproducibility of diagrams: In our study, students opined that $C \& B$ method is much better than PPT as far as reproducibility of diagrams is concerned $(p \varangle 0.0001)$.
$M$ any students opined that the diagrams on PPT though attractive, cannot be copied. Many topics in anatomy rely heavily on illustrations for proper understanding. Therefore certain descriptive answers require presence of diagrams. A single diagram is equal to thousand words, clarifies many complex concepts.

Retention of lecture information in memory: Our students opined that $C \& B$ lectures are more helpful to retain the lecture information in memory $(p=0.0318)$, statistically significant. While explaining with $C \& B$ only the important points are written on board. Hence these points get imbibed on students mind. M oreover, these points are on the board for a longer period, helping the students to learn those. In contrast, the text on PPT is comparatively more, thus the important points, may not be given due weightage.

Table 1: Comparison between ppt and chalk and board with respect to various parameters. N: 160.

\begin{tabular}{|c|l|c|c|c|c|}
\hline SI N0. & \multicolumn{1}{|c|}{ Parameters } & C\&B & PPT & Z-value & p-value \\
\hline 1 & Help to understand concept & 95 & 65 & 3.2 & 0.0013 \\
\hline 2 & Help to memorize the topic & 90 & 70 & 2.1 & 0.0318 \\
\hline 3 & $\begin{array}{l}\text { Reproducibility to text information during } \\
\text { theory examination }\end{array}$ & 92 & 68 & 2.7 & 0.0073 \\
\hline 4 & $\begin{array}{l}\text { Reproducibility of text information during } \\
\text { viva }\end{array}$ & 85 & 75 & 1.1 & 0.2831 \\
\hline 5 & Reproducibility of diagrams & 112 & 48 & 7.2 & $\varangle .0001$ \\
\hline 6 & Visualization of pictures with colors & 51 & 109 & 6.4 & $\varangle .0001$ \\
\hline 7 & Which method is interesting & 82 & 78 & 0.4 & 0.7205 \\
\hline 8 & Which method should be used & 90 & 70 & 2.1 & 0.0318 \\
\hline
\end{tabular}

\section{DISCUSSION}

Seth et al, 2010b in a study to assess the teacher's preference to the teaching methods, observed that $40.47 \%$ of teachers in their study group preferred C\&B. Thomas and Appala, noted that as per students opinion, the explanations, clarity of concepts and learning to draw diagrams are better done on C\&B than PPT [7]. Teacher student interaction is better in $C \& B$ method. It allows spontaneity, flexibility and nonlinearity. It is flexible enough to allow the teacher to elaborate a particular point, if he wishes so. Students are able to make their notes/ diagrams, thus students are active learners. The lectures are not interrupted due to power failure [5].

It also contains natural pauses e.g. during cleaning of board (seth 2010c) which provides 
sufficient time to the students to grasp the new concepts. In C\&B method as the teacher teaches, he/she is a single source for both the auditory as well as visual information for students. This enables them to concentrate easily. This is in contrast to use of PPT where the students receive inputs from two different sources i.e auditory inputs from teacher (usually standing at the computer) while the visual inputs from the screen [5].

Along with these advantages, $C \& B$ do carry few disadvantages too. It requires more preparation and hence is more strenuous for teacher. Complicated diagrams, 3D diagrams, photographs, video clips etc cannot be presented by this method. Only limited material can be conveyed to the students. The drawing skills and handwriting of the teacher need to be good. So also condition of board and poor visibility of the text are the other noteworthy drawbacks pointed out by our students [5].

Good quality colored 3D diagrams, good visibility and legibility of text are the points in favour of PPT. likewise clarity of words, illustrations, real pictures and summarization were some of the attributes described to be best dealt with РPT(7). From teachers point, we feel that, teacher is more relaxed; as he can conduct the lecture even though he is not well prepared, large materials can be conveyed by this method [5].

\section{CONCLUSION}

The results of the present study suggest that blackboard has the advantages of better recall besides being the most preferred aid among medical students. There is a need to discuss as to why a traditional method has more preference over a new method. This study should be considered as a guide by all streams of medicine to improve the uses of black board teaching and to consider it a supplement to the PPT.

\section{ABBREVIATION:}

PPT- Power point,

C\&B-Chalk and Board.

\section{Conflicts of Interests: None}

\section{REFERENCES}

[1]. Brown G and Atkins M ; Effective teaching in higher education. $1^{\text {st }}$ edition, London, UK: Methuen and Co.Ltd. 1988:105.

[2]. Cannon R;Lecturing: green guide no.7, $1^{\text {st }}$ edition, Kensington, N.S.W; Higher Education Research and Development Society of Australia, 1988:47.

[3]. Walton AJ; Lectures, tutorials and the like. $1^{\text {st }}$ edition, Medical \& Technical Publishing Co. Ltd. Lancaster, UK, 1972:103.

[4]. S. Waheeda, K Sathiya M urthy, A comparative study of blackboard teaching with Powerpoint teaching in 1 year medical students, National J of Basic M edical Sciences 2015;6(1).

[5]. Rokade S A, Bahetee B H, Shall we teach Anatomy with Chalk and Board or Power Point Presentations?- An Analysis of Indian Students Perspectives and Performance, Sch. J. App. Med. Sci., 2013; 1(6);837-842.

[6]. Ding Xingeng, Liu Jianxiang, Advantages and Disadvantages of Power Point in Lectures to science students, I.J. Education and $M$ anagement Engineering 2012;9:61-65.

[7]. Thomas M , Appala Raju B; Are Power Point presentations fulfilling its purpose? Southeast Asian Journal of Medical Education, 2007;1(1):38-41.

\section{How to cite this article: \\ Rashmi C Goshi. POWER POINT OR CHALK AND BOARD - STUDENTS VIEW TOWARDS M ETHOD OF TEACHING ANATOMY. Int J Anat Res 2017;5(1):3510-3512. DOI: 10.16965/ijar.2016.516}

